\title{
Lysozyme activity in plasma and leucocytes in malnourished children
}

\author{
By M. MOHANRAM, VINODINI REDDY AND S. MISHRA \\ National Institute of Nutrition, Indian Council of Medical Research, \\ famai-Osmania, Hyderabad-500007, India
}

(Received I6 October 1973-Accepted 20 February 1974)

\begin{abstract}
I. Lysozyme activity was estimated in plasma and leucocytes of twelve children suffering from kwashiorkor, thirteen children with ocular signs of vitamin A deficiency and ten apparently normal children acting as controls.

2. The results showed that the activity of lysozyme in leucocytes was significantly reduced in children with kwashiorkor and in vitamin A-deficient children. Following therapy, the levels of the enzyme in leucocytes were restored to normal.

3. The initial enzyme activity in the plasma of both groups of children did not differ significantly from the control value, and was not significantly changed after treatment.

4. It is suggested that the decreased activity of lysozyme is one of the factors responsible for diminished resistance to infection generally observed in malnourished children.
\end{abstract}

It is generally agreed that malnutrition contributes to increased morbidity and mortality from infection. Previous studies at this Institute (Selvaraj \& Bhat, I972a,b) have demonstrated that leucocytes obtained from children suffering from proteinenergy malnutrition have impaired phagocytic and bactericidal activities. This may partly explain the reduced resistance to infection observed in advanced states of protein-energy malnutrition. It is now accepted that lysozyme also has an important role in the process of resistance to infection. There is, however, no information about lysozyme content in conditions of nutritional stress. We therefore estimated the levels of lysozyme in both plasma and leucocytes of malnourished children.

\section{EXPERIMENTAL}

\section{Subjects}

Twelve children suffering from kwashiorkor and thirteen children with ocular signs of vitamin A deficiency were investigated. In addition, ten normal children were studied for comparison. These were siblings of the patients admitted to the hospital and they were apparently healthy at the time of the study. The ages of these children ranged from 2 to 7 years. Children suffering from kwashiorkor had oedema and hypoalbuminaemia. The children with vitamin A deficiency had conjunctival xerosis or Bitot's spots or both.

Children suffering from kwashiorkor were hospitalized and rehabilitated for a period of 4 weeks with a diet providing $4 \mathrm{~g}$ protein $/ \mathrm{kg}$ body-weight and $0.84 \mathrm{MJ}$ $(200 \mathrm{kcal}) / \mathrm{kg}$ body-weight daily. Fasting samples of blood were taken from these children at the time of admission and again at the end of treatment. Children with vitamin A deficiency were treated as out-patients and were given oral doses of $800 \mu \mathrm{g}$ 
Table I. Plasma concentrations of retinol and albumin and levels of lysozyme in plasma and leucocytes of children with kwashiorkor and vitamin $A$ deficiency

\begin{tabular}{|c|c|c|c|c|c|c|c|c|c|}
\hline & (Mea & alues & h t & eir sta & 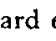 & ors) & & & \\
\hline & & & & & & & & ozyme & \\
\hline & No. & $\begin{array}{r}\text { reti } \\
(\mu g \\
-\end{array}$ & & $\begin{array}{r}\text { albu } \\
\end{array}$ & & & & $\begin{array}{r}\text { Leu } \\
(\mu \mathrm{g})\end{array}$ & $\begin{array}{l}\text { cytes } \\
\text { cells) }\end{array}$ \\
\hline Subjects & subjects & Mean & $\mathrm{SE}$ & Mean & SE: & Mean & SE & Mean & st: \\
\hline $\begin{array}{l}\text { Normal } \\
\text { Kwashiorkor: }\end{array}$ & IO & - & -- & 39 & 0.5 & $8 \cdot 9$ & 0.78 & $3 \cdot 7$ & 0.41 \\
\hline On admission & 12 & - &..- & 20 & $I \cdot I$ & $8 \cdot 3$ & 0.94 & $I \cdot I$ & 0.18 \\
\hline After treatment & 12 & - & -- & $3^{6 *}$ & $\mathrm{I} \cdot 3$ & $6 \cdot 3$ & 0.47 & $3 \cdot 4^{*}$ & 0.09 \\
\hline Vitamin A-d & & & & & & & & & \\
\hline On admission & I 3 & 99 & 14.7 & 33 & $1 \cdot 3$ & $9 \cdot 9$ & $1 \cdot 22$ & $1 \cdot 5$ & 0.21 \\
\hline After treatment & 13 & $241 *$ & $15 \cdot 6$ & $\cdots$ & - & 9.4 & $1 \cdot 18$ & $2 \cdot 5^{*}$ & 0.23 \\
\hline
\end{tabular}

Difference in the levels before and after treatment was tested using paired $t$ test.

*P<0.001.

retinoyl palmitate/d for a period of $10 \mathrm{~d}$. Fasting samples of blood were taken before and after treatment. Mothers' consent was obtained before blood samples were collected.

\section{Methods}

Vitamin A levels were estimated as retinol by the spectrophotometric method of Gopalan, Venkatachalam \& Belavady (1960) and serum albumin levels were determined by the micro-Kjeldahl method (Oser, I965). The lysozyme content of plasma and leucocytes was estimated by the bacteriolytic method of Harrison, Lunt, Scott \& Blainey (1968).

Leucocytes were separated by the dextran flotation technique (Mohanram \& Srikantia, 1967). The suspension of leucocytes in dextran solution was homogenized for 2-3 min using a Potter-Elvchjem homogenizer to disrupt cells and release lysozyme. The homogenate was then repeatedly frozen and thawed. The levels of lysozyme were estimated by the lysis of a freshly-prepared suspension of dricd cells of Micrococcus lysodeikticus (Sigma Chemicals Co., St Louis, Missouri, USA) in 0.067 Msodium phosphate buffer, $\mathrm{pH} 6 \cdot 2$, using a standard (crystalline egg-white lysozyme from Sigma Chemical Co., St Louis, Missouri, USA), plasma or leucocytc suspension, $0.5 \mathrm{ml}$ being added to $5.0 \mathrm{ml}$ of the bacterial cell suspension and mixed by shaking. The decrease in turbidity was measured by the changes in extinction at $45^{\circ} \mathrm{nm}$, $30 \mathrm{~s}$ and Io min after mixing. A series of standard solutions were analysed with each group of samples, and the results are expressed in terms of crystalline egg-white lysozyme.

\section{RESULTS}

Children with kwashiorkor. Table I shows that when this condition was most severe the mean levels of plasma albumin were very low $(20 \mathrm{~g} / 1)$, increasing significantly $(P<0.00 \mathrm{I})$ after treatment with a high-protein $\operatorname{diet}(36 \mathrm{~g} / \mathrm{l})$. Lysozyme activity 
in the leucocytes of these children was significantly reduced compared with that of normal children $(P<0 \cdot 001)$. Following therapy, the activity increased from $I^{\cdot} 1 \pm 0 \cdot 18$ to $3.4 \pm 0.09 \mu \mathrm{g} / \mathrm{I}^{6}$ cells $(P<0.00 \mathrm{I})$. Though the amount of the enzyme in plasma was slightly lower after treatment, the decrease was not statistically significant (tested by paired $t$ test).

Children with vitamin $A$ deficiency. Initial levels of plasma retinol were low $(99 \pm 14.7 \mu \mathrm{g} / \mathrm{l})$ and increased significantly $(P<0.001)$ after administration of retinol $(24 \mathrm{I} \pm \mathrm{I} 5.6 \mu \mathrm{g} / \mathrm{l})$. Plasma albumin levels were normal in all these children. The initial mean lysozyme content of leucocytes of children suffering from vitamin A deficiency was significantly lower $(P<0.00 \mathrm{r})$ than that of normal children. The mean lysozyme content of the leucocytes increased significantly $(P<0.00 x)$ from a mean initial level of $I^{\cdot} 5 \pm 0 \cdot 2 \mathrm{I}$ to $2 \cdot 5 \pm 0.23 \mu \mathrm{g} / \mathrm{IO}^{6}$ cells after treatment with vitamin $\mathrm{A}$, but it was still lower than that of normal children. The initial activity of the enzyme in plasma was not significantly different from the control value and remained unchanged after treatment.

\section{DISCUSSION}

Results of these studies clearly indicate that, compared with that of normal children, the lysozyme content of the leucocytes is markedly reduced in children with kwashiorkor and in those with vitamin A deficiency. It is well established that lysozyme has a vital role in the defence mechanism against bacterial and viral infections. In experimental animals it has been demonstrated that lysozyme has not only a prophylactic but also has a therapeutic effect in staphylococcal and Escherichia coli infections (Ermol'eva, Furer, Ravich, Navashin, Braude, Fomina, Zhukovskaya, Balezina, Ved'mina, Golosova, Nemirovskaya \& Terent'eva, 1964). Results of tissue culture experiments indicated that the enzyme suppresses the development of the cytopathogenic effect of influenza virus and adenovirus (Ermol'eva et al. 1964).

Selvaraj \& Bhat $(1972 a, b)$ have shown a change in phagocytic metabolism and a decrease in bactericidal potency of leucocytes isolated from children with kwashiorkor. It is now generally accepted that lysozyme has a significant role in bactericidal reactions (Cohn \& Hirsch, 1960; Davis, Gemsa, Iannetta \& Wedgwood, 1968). It is possible that the reduced bactericidal activity found in children with kwashiorkor may be the result of decreased levels of lysozyme in the leucocytes. It has been reported that activities of several enzymes in serum (lipase, amylase, alkaline phosphatase, pseudocholinesterase and creatine kinase) are significantly reduced in children with kwashiorkor (Waterlow, I950; Srinivasan \& Patwardhan, I952; Dean \& Schwartz, 1953; Schwartz, 1956; Edozien, 1961; Balmer \& Rutishauser, 1968; Reindorp \& Whitehead, 1971). The decreased activity of these enzymes may reflect decreased synthesis of the enzyme in the liver, as the activity of certain enzymes are also low in this organ (Waterlow, 1950; Mukherjee \& Sarkar, 1958). It may be suggested therefore that the low levels of leucocyte lysozyme we found in children with kwashiorkor could also be the result of decreased synthesis of the enzyme in the leucocyte, associated with protein deficiency.

The children suffering from vitamin A deficiency were found to have low levels of 
lysozyme in the leucocytes. Lysozyme has been shown to be of lysosomal origin (Gordis, I966). Vitamin A deficiency is known to result in the labilization of lysosomes and therefore in the release of lysosomal enzymes from cells (Guha \& Roels, I965; Dingle, Sharman \& Moore, I966). Our previous studies have shown that urinary excretion of the lysosomal enzymes aryl sulphatase and acid phosphatase is increased in children with vitamin A deficiency (Reddy \& Mohanram, I97I). It was suggested that the increased excretion of these enzymes may be the result of increased instability of lysosomes. But this is unlikely in the subjects studied here because the activity of the enzyme in plasma was not elevated. It is possible that decreased amounts of lysozyme in children with vitamin A deficiency may be the result of reduced synthesis of the enzyme.

In the children with vitamin A deficiency, the levels of plasma albumin were found to be normal, which suggests that vitamin A deficiency per se had brought about the changes in the enzyme levels and this effect is not the result of associated protein deficiency. This is further substantiated by the finding that the enzyme levels in leucocytes showed a marked increase following administration of vitamin $A$ alone. The decreased activity of lysozyme in leucocytes appears to be one of the important factors responsible for the reduced resistance to infection found in malnourished children.

We wish to thank Dr C. Gopalan (Director) and Dr S. G. Srikantia (Deputy Director), National Institute of Nutrition, Hyderabad, for their helpful suggestions.

\section{REFERENCES}

Balmer, S. E. \& Rutishauser, I. H. E. (1968). F. Pediat. 73, 783 .

Cohn, Z. A. \& Hirsch, J. G. (1960). F. exp. Med. r12, ror 5 .

Davis, S. D., Gemsa, D., Iannetta, A. \& Wedgwood, R. J. (1968). f. Immun. ror, 277.

Dean, R. F. A. \& Schwartz, R. (1953). Br. F. Nutr. 7, I31.

Dingle, J. T., Sharman, I. M. \& Moore, T. (1966). Biochem. F. 98, 476.

Edozien, J. C. (1961). Pediatrics, Springfield 27, 325.

Ermol'eva, Z. Y., Furer, N. M., Ravich, I. V., Navashin, S. M., Braude, A. I., Fomina, I. P., Zhukovskaya, N. A., Balezina, T. I., Ved'mina, E. A., Golosova, T. V., Nemirovskaya, B. M. \& Terent'eva, T. G. (1964). Fedn Proc. Fedn Am. Socs exp. Biol. 23, T 75.

Gopalan, C., Venkatachalam, P. S. \& Belavady, B. (1960). Am. J. clin. Nutr. 8, 833 .

Gordis, L. (1966). \%. Pediat. 68, 638 .

Guha, A. \& Roels, O. A. (1965). Biochim. biophys. Acta х1г, 364 .

Harrison, J. F., Lunt, G. S., Scott, P. \& Blainey, J. D. (1968). Lancet i, 371.

Mohanram, M. \& Stikantia, S. G. (1967). Clin. Sci. 32, 215.

Mukherjee, K. L. \& Sarkar, N. K. (1958). Br. F. Nutr. r2, 1.

Oser, B. L. (1965). Hawk's Physiological Chemistry, 14th ed., pp. 1081, 1219. New York: McGrawHill.

Reddy, V. \& Mohanram, M. (197I). Int. Z. VitamForsch. 4I, 32 I.

Reindorp, S. \& Whitehead, R. G. (197I). Br. F. Nutr. 25, 273.

Schwartz, R. (1956). F. clin. Path. 9, 333 .

Selvaraj, R. J. \& Bhat, K. S. (1972a). Biochem. F. 127, 255.

Selvaraj, R. J. \& Bhat, K. S. $(1972 b)$. Am. F. clin. Nutr. 25, I 66.

Srinivasan, P. R. \& Patwardhan, V. N. (1952). Lancet ii, 864.

Waterlow, J. C. (1950). Lancet i, 908. 